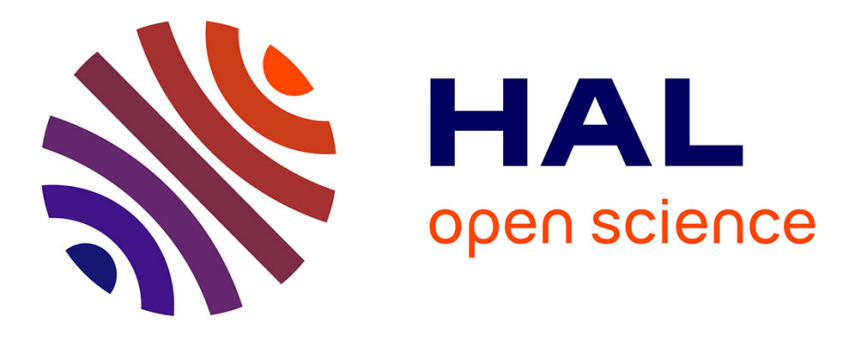

\title{
In vitro testing of new somatostatin analogs on pituitary tumor cells
}

Maria Chiara Zatelli, Maria Rosaria Ambrosio, Marta Bondanelli, Ettore C. Degli Uberti

\section{- To cite this version:}

Maria Chiara Zatelli, Maria Rosaria Ambrosio, Marta Bondanelli, Ettore C. Degli Uberti. In vitro testing of new somatostatin analogs on pituitary tumor cells. Molecular and Cellular Endocrinology, 2008, 286 (1-2), pp.187. 10.1016/j.mce.2007.12.010 . hal-00531975

\section{HAL Id: hal-00531975 \\ https://hal.science/hal-00531975}

Submitted on 4 Nov 2010

HAL is a multi-disciplinary open access archive for the deposit and dissemination of scientific research documents, whether they are published or not. The documents may come from teaching and research institutions in France or abroad, or from public or private research centers.
L'archive ouverte pluridisciplinaire HAL, est destinée au dépôt et à la diffusion de documents scientifiques de niveau recherche, publiés ou non, émanant des établissements d'enseignement et de recherche français ou étrangers, des laboratoires publics ou privés. 


\section{Accepted Manuscript}

Title: In vitro testing of new somatostatin analogs on pituitary tumor cells

Authors: Maria Chiara Zatelli, Maria Rosaria Ambrosio, Marta Bondanelli, Ettore C. degli Uberti

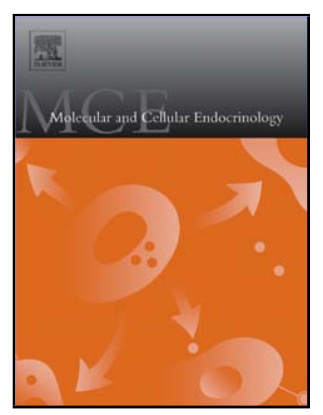

PII:

S0303-7207(07)00475-3

DOI: doi:10.1016/j.mce.2007.12.010

Reference: MCE 6774

To appear in: $\quad$ Molecular and Cellular Endocrinology

Received date: $\quad 30-5-2007$

Revised date: 3-12-2007

Accepted date: $\quad$ 17-12-2007

Please cite this article as: Zatelli, M.C., Ambrosio, M.R., Bondanelli, M., degli Uberti, E.C., In vitro testing of new somatostatin analogs on pituitary tumor cells, Molecular and Cellular Endocrinology (2007), doi:10.1016/j.mce.2007.12.010

This is a PDF file of an unedited manuscript that has been accepted for publication. As a service to our customers we are providing this early version of the manuscript. The manuscript will undergo copyediting, typesetting, and review of the resulting proof before it is published in its final form. Please note that during the production process errors may be discovered which could affect the content, and all legal disclaimers that apply to the journal pertain. 
In vitro testing of new somatostatin analogs on pituitary tumor cells

Maria Chiara Zatelli, Maria Rosaria Ambrosio, Marta Bondanelli, Ettore C degli Uberti

Section of Endocrinology, Dept.of Biomedical Sciences and Advanced Therapies, University of Ferrara - 44100 Ferrara, ITALY

Corresponding Author:

Maria Chiara Zatelli, MD

Section of Endocrinology, Dept.of Biomedical Sciences and Advanced Therapies

University of Ferrara

Via Savonarola 9

44100 Ferrara, ITALY

Phone: +390532 237397

Fax: +390532 236514

E-mail: ztlmch@unife.it 
Key words: pituitary, somatostatin, somatostatin analogs, somatostatin receptors.

\section{ABSTRACT}

Somatostatin has been discovered as a somatotroph release inhibitory factor (SRIF), and, indeed, it has been demonstrated that SRIF and its analogs can inhibit pituitary tumor hormone secretion and control neoplastic bulk. Several in vitro studies have contributed to the current knowledge of the mechanisms by which SRIF and its analogs may influence pituitary adenomas, opening the way to new possible therapeutic strategies.

This review focuses on the results obtained by testing several SRIF analogs in vitro on pituitary adenomas, concerning both secretory activity and cell viability. These studies provide the basis for further investigations, both at basic and clinical level, of the application of SRIF analogs in the pituitary field.

The discovery of the antisecretory properties of somatostatin (SRIF) on normal and neoplastic pituitary cells prompted many in vitro studies investigating the possible effects of new SRIF analogs on pituitary adenomas.

It has been indeed demonstrated that native SRIF inhibits secretion and proliferation of both normal and neoplasic pituitary cells by inducing several intracellular pathways, depending on receptor subtype and target tissue (Ferjoux et al. 2000). Therefore, many studies subsequently explored SSTR subtype expression in pituitary adenomas, demonstrating that SSTR2 is the most frequently expressed subtype (Panetta and Patel, 1995). This evidence provided the basis for the use of SRIF analogs in medical therapy of pituitary adenomas, in the attempt to restrain tumor growth and function.

In vitro data, however, clarified that old and new SRIF analogs might differently influence pituitary cell functions in vitro. Danila et al. studied 15 GH-secreting pituitary adenomas, where 
SSTR 2 and 5 mRNA were always expressed, while SSTR 1 and 3 mRNA were expressed in 11 and 12 tumors, respectively. Primary cultures deriving from these tumors were tested with $1 \mu \mathrm{M}$ SRIF or lanreotide (Lan), a SRIF analog preferentially binding with high affinity SSTR2 and less affinity SSTR5, or with SSTR2- and SSTR5-selective analogs. After 24 hours no effect was observed in some cultures, but in others (as well as in the GH3 rat cell line) a parallel reduction in cell viability and DNA synthesis was observed. This study also highlighted a dissociation between the in vitro effects of SRIF analogs on tumor cell proliferation and on GH secretion. In nearly $60 \%$ of the tumors, treatment with SRIF, Lan, SSTR2- or SSTR5-selective agonists significantly inhibited GH secretion.by a median of $33 \%$. However, not all these primary cultures responded to SRIF and its analogs in terms of cell viability reduction, suggesting that inhibition of cell proliferation occurs independently of the effects on GH secretion (Danila et al. 2001). Similarly, an important tumor shrinkage has been described in an acromegalic patient during primary therapy with SRIF analogs, in the absence of hormonal normalization (Casarini et al. 2006). In this case, the lack of antisecretory action of octreotide, a SRIF analog preferentially binding with high affinity SSTR2 and less affinity SSTR5, was in keeping with the absence of SSTR2 and SSTR5 expression by the tumor, which expressed almost exclusively SSTR3. The latter SSTR subtype has been indeed demonstrated to transduce important antiproliferative signals, since its activation causes apoptosis in heterlogous expression systems (Sharma et al. 1996). Further support to the hypothesis that antiproliferative effects are independent of antisecretory actions of SRIF analogs is provided by a recent report, describing the case of an acromegalic patient displaying dramatic tumor shrinkage during primary therapy with octreotide, without hormonal normalization. Again, in vitro SRIF and its analogs at $10 \mathrm{nM}$ induced a scant antisecretory effect, but potently inhibited thymidine incorporation. This effect was evident for compounds interacting with SSTR5, in keeping with the finding that SSTR5 expression levels were greater than SSTR2 in the tissue (Resmini et al. 2007). These findings further underline that activation of multiple receptors by new analogs may better 
control tumor cell activity and that SRIF analogs may induce tumor shrinkage despite the lack of effect on GH secretion.

Further studies highlighted the importance of SSTR expression pattern in GH-secreting pituitary adenomas in respect to the inhibitory effects of SRIF analogs. In a series of 16 adenomas a selective SSTR5 agonist (BIM-23268 at 0.01-1 $\mu \mathrm{M}$ ) was more potent of a selective SSTR2 agonist (NC-4-28B at $0.01-1 \mu \mathrm{M}$ ) in reducing GH secretion in primary cultures not responding to SRIF (Tulipano et al. 2001). These results suggest that SRIF analogs with greater affinity for SSTR5 might enhance treatment potency and spectrum in acromegaly, especially in octreotide-resistant patients.

The mechanism by which SRIF inhibits pituitary cell proliferation has been investigated in the GH3 rat pituitary cell line, where $10 \mu \mathrm{g} / \mathrm{ml}$ octreotide and a chimeric compound, formed by GH releasing peptide linked to SRIF, significantly inhibited cell proliferation by activating tyrosine phosphatases (PTP), involving a cGMP-dependent pathway (Dasgupta et al. 1999). There is also evidence that PTP-dependent apoptotic changes can be induced by treatment of somatotroph pituitary adenoma cells by octreotide and by a selective SSTR2 agonist, BIM-23120 at $10 \mathrm{nM}$ (Ferrante et al. 2006). PTPs are indeed listed among the pathways activated by SSTRs triggering cell proliferation inhibition (Weckbecker et al. 2003), especially SHP-1, which we demostrated to control cell proliferation in a human medullary thyroid carcinoma cell line upon SSTR2 activation (Zatelli et al. 2005a). In somatotroph pituitary adenomas showing clearly detectable levels of SSTR2 and SSTR5 mRNA and proteins, selective SSTR2 activation causes growth arrest by an increase in p27 and a decrease in cyclin D1 expression, promoting apoptosis (Ferrante et al. 2006). Previous studies by Luciani et al. (Luciani et al. 2005) showed that $10 \mathrm{nM}$ octreotide treatment induces apoptosis in GH-secreting adenomas expressing SSTR2 and SSTR5 at the same level, where a reduced expression of the anti-apoptotic gene seladin-1 was found as compared to non functioning pituitary adenomas (NFA). In addition, SRIF analogues have been shown to produce their antiproliferative action by acting on the PI3K/Akt signaling pathway and increasing Zac1 gene 
expression at 1-100 $\mathrm{nM}$ in GH3 cells. Zac1 induces cell cycle arrest and apoptosis and is highly expressed in normal pituitary, mammary, and ovarian glands but is down-regulated in pituitary, breast, and ovarian tumors, suggesting that it might act as an oncosuppressor gene (Theodoropoulou et al. 2006). Taken together, these results confirm that SSTR2 is an important receptor subtype to transduce the antiproliferative signals of SRIF, but also suggest that more than one SSTR is able to induce antiproliferative effects. At the same time, multiple subtypes may co-operate to induce growth arrest, also in the light of the recent advances on SSTR biology, indicating the possibility for these receptors to homo- and hetero-dimerize with other G-Protein coupled receptors (GPCRs) (Rocheville et al. 2000). It has indeed been recently demonstrated that, in an animal model, in basal conditions SSTR2 forms constitutive homodimers/homomultimers, which rapidly dissociate upon ligand binding. In addition, porcine SSTR2 displays peculiar agonist-dependent dimerization, dissociation, internalization, and reassociation (Duran-Prado et al. 2007). Tulipano et al. also demonstrated that, after ligand binding, SSTR2 is phosphorylated by G protein-coupled receptor kinase 2, forms a stable complex with beta-arrestin and then internalizes into endocytic vesicles. However, SSTR2 is rapidly resensitized and recycled to the plasma membrane. Conversely, after activation, SSTR3 and SSTR5 rapidly dissociate from beta-arrestin and undergo ubiquitindependent lysosomal degradation, preventing plasma membrane recycling (Tulipano et al. 2004). These findings might explain the different down-stream effects observed in different experimental settings.

In light of the recent discoveries concerning SSTR biology, we attempted to clarify the possible functional interaction between SSTR and dopamine (DA) receptor subtype 2 (DR2). To this aim, we investigated DR2 and SSTR2 and 5 expression in 25 GH-secreting pituitary adenomas, which were tested in primary culture with the SSTR2-selective agonist (BIM-23120), the SSTR5selective agonist (BIM-23206), or the dual SSTR2/5 bi-selective agonist (BIM-23244) at $10 \mathrm{nM}$. Expression studies showed that all samples expressed SSTR2; 8 samples expressed both SSTR5 and DR2, 8 expressed SSTR5 and 8 expressed DR2. GH secretion was inhibited by BIM-23120 in all 
samples, while it was reduced by BIM-23206 only in adenomas not expressing DR2. The inhibitory effects of the SSTR2-selective agonist directly correlated with SSTR2 and DR2 expression, whereas DR2 expression inversely correlated with the inhibitory effects of the SSTR5-selective agonist on GH secretion. In 7 mixed GH-/PRL-secreting pituitary adenomas, PRL secretion was inhibited in SSTR5-expressing tumors by the SSTR5-selective agonist, but not by SSTR2-selective agonist. The dual SSTR2/5 bi-selective agonist, BIM-23244, was capable of inhibiting PRL secretion only in adenomas expressing SSTR2, SSTR5 and DR2. In addition, we found that SSTR5 and DR2 expression directly correlated with the inhibitory effects ot the SSTR5-selective agonist on PRL secretion. These results suggest that GH-secreting pituitary adenomas expressing DR2 are less likely to respond to clinically available SRIF analogs in terms of GH secretion inhibition. Therefore, drugs interacting also with DR2 might better control secretion of pituitary adenomas (Zatelli et al. 2005 b). In addition, the reported evidence suggests that the simultaneous expression of different SSTRs and DRs might deeply influence the effects of receptor ligands, likely modifying receptors dynamic interactions.

In order to clarify the role of SSTR different from SSTR2 in transducing SRIF inhibitory effects, we investigated SSTR1 activation in pituitary adenomas. A group of 15 GH-secreting pituitary adenomas expressing SSTR1 was therefore selected and treated with SRIF or with a SSTR1 selective agonist, BIM-23926 at $10 \mathrm{nM}$, in primary culture. Treatment with SRIF or with the SSTR1 selective agonist significantly inhibited GH and PRL secretion as well as cell viability. Moreover, a significant positive correlation between the inhibitory effects of BIM-23926 on GH and PRL secretion and SSTR1 mRNA expression was found. However, such correlation was not apparent concerning the antiproliferative effect, suggesting that even very low SSTR1 expression levels migh trasduce SSTR1 selective agonist inhibitory effects on cell viability in GH-secreting pituitary adenomas (Zatelli et al. 2003). These results indicate that also SSTR1 may mediate SRIF actions at pituitary level, identifying SSTR1 as a potential target for new therapies aimed at controlling growth and hormonal secretion of pituitary tumors. This hypothesis is further supported 
by the finding that a SSTR1 selective agonist at 10-100 $\mathrm{nM}$ significantly inhibits GH secretion in vitro also in tumors from acromegalic patients resistant to octreotide or Lan therapy (Matrone et al. 2004). The importance of SSTR1 as a possible target for medical therapy of pituitary adenomas was further underlined by a study performed on a selected group of 12 NFA, all expressing SSTR1, SSTR2, and SSTR5, as well as Chromogranin A (CgA) and $\alpha$-subunit. In these settings, SSTR1 and SSTR2 selective agonists at $10 \mathrm{nM}$ were found to significantly inhibit both $\alpha$-subunit and $\operatorname{CgA}$ secretion by NFA primary cultures. Moreover, only the SSTR1 selective agonist was capable of significanly reducing in vitro cell viability. Again, the inhibitory effects of the SSTR1 selective agonist did not correlate with the extent of SSTR1 expression, further supporting the hypothesis that even very low SSTR1 expression might transduce the inhibitory effects of the SSTR1 selective agonist (Zatelli et al. 2004). These results suggest that SRIF analogs with enhanced potency for SSTR1 could offer useful tools for NFA medical therapy. On the other hand, this study showed that treatment of the selected NFA with the SSTR5 selective agonists, BIM-23206, at $10 \mathrm{nM}$ did not influence the secretory activity, but significantly promoted cell viability. Previous data showed that SSTR5 mediates PRL secretion inhibition induced by SRIF and its analogs at $100 \mathrm{nM}$ in pure PRLand in mixed GH/PRL- secreting adenomas, as well as the suppression of GH secretion in somatotroph cells, together with SSTR2 (Shimon et al. 1997a, Shimon et al. 1997b). Moreover, Jaquet et al demonstrated that SSTR2 and SSTR5 selective agonists have additive effects (Jaquet et al. 2000), and a bi-selective SSTR2/SSTR5 agonist has enhanced efficacy in suppressing GH secretion from octreotide-resistant human GH-secreting adenomas (Saveanu et al. 2001). In addition, a functional association between SSTR2 and SSTR5 in inhibiting GH secretion has been suggested (Ren et al. 2003). On the contrary, our data show that the SSTR2 selective agonist did not influence NFA cell viability, which was promoted by the SSTR5 selective agonist. This effect might explain the lack of efficacy of medical treatment by means of octreotide or Lan, compounds mainly interacting with SSTR2 and less with SSTR5, in some NFA (Oppizzi et al. 1998, Andersen et al. 2001, Colao et al. 2000, Gasperi et al. 1993). Moreover, our findings might provide a possible 
explanation for the increase in tumor volume rarely observed during such therapy (Andersen et al. 2001). These results suggest that indication for medical therapy with octreotide or Lan in NFA patients with SSTR5 expressing tumors should be critically discussed until clinical evidence for beneficial effects has clearly been demonstrated. Selective SSTR5 activation has previously been demonstrated to promote cell proliferation in a medullary thyroid carcinoma (MTC) cell line (Zatelli et al. 2001), but not in GH-secreting pituitary adenomas in primary culture (Danila et al. 2001). Therefore, it is likely that SSTR agonists differently affect hormone secretion and cell proliferation depending not only on the activated receptor subtype, but also on the specific tissue. And indeed there is evidence indicating that SSTR5 is important in transducing SRIF inhibitory effects in a mouse ACTH-secreting pituitary adenoma cell line, the AtT20 cells (Richardson et al. 1981; van der Hoek et al. 2005). Indeed, upon SRIF treatment, SSTR5 persists at the membrane level while SSTR2 rapidly internalizes and desensitizes (Ben-Shlomo et al. 2005). Further studies on human ACTH-pituitary adenomas in vitro demonstrated that pasireotide (SOM230, a novel SRIF analog interacting with all SSTRs except for SSTR4) at $10 \mathrm{nM}$ significantly inhibits ACTH release in primary cultures predominantly expressing SSTR5. In addition, in these settings octreotide was less effective in reducing ACTH secretion, and dexamethasone $(10 \mathrm{nM})$ pre-treatment did not influence the sensitivity of the cells to the inhibitory effect of SOM230. These data indicate that SSTR5 is relatively resistant to negative control by glucocorticoids (Hofland et al 2005), as also suggested by an animal model. Indeed, treatment with pasireotide significanlty down-regulated SSTR2 but not SSTR5 expression. in the AtT20 cell line (van der Hoek et al. 2005). These results have been further strengthened by the recent evidence that pasireotide is capable of reducing both ACTH secretion and cell proliferation of human corticotroph pituitary adenoma cultures, where receptor expression has been characterized at protein level (Batista et al. 2006). All together, these results provide further support to the hypothesis that SSTR5 has an inhibitory activity on corticotroph cell functions and is required to warrant efficacy of SRIF analogs in the treatment of patients with ACTH-secreting pituitary adenomas. 
It has been recently demonstrated that treatment of dispersed GH-secreting pituitary adenoma cells, having a variable SSTR expression pattern, with octreotide at $10 \mathrm{nM}$, as well as with pasireotide at $10 \mu \mathrm{M}$, up-regulates the expression of a cyclin-dependent kinase inhibitor, p27, possibly resulting in cell cycle inhibition (Hubina et al. 2006). Besides the antiproliferative effects, previous studies showed that pasireotide at $10 \mathrm{nM}$ is capable of significantly inhibiting GH secretion in primary cultures deriving from human GH-secreting pituitary adenomas, mainly expressing SSTR2 and SSTR5 (Hofland et al. 2004; Murray et al. 2004). SSTR2 expression was found to be crucial, as underlined by the positive correlation between SSTR2 mRNA levels and pasireotide effects in vitro. Such correlation was not found for SSTR5, suggesting that pasireotide exerts its inhibitory effects on GH-secreting pituitary adenomas mainly interacting with SSTR2 (Hofland et al. 2004). This finding is in keeping with a previous report showing that SSTR2 but not SSTR5 mRNA expression correlates with the extent of GH inhibition induced by SRIF in GHsecreting pituitary adenomas (Jaquet et al. 2000). On the other hand, there is evidence indicating that in prolactinomas and in mixed GH/PRL pituitary adenomas, PRL secretion inhibition is mainly transduced by SSTR5 (Jaquet et al. 1999; Jaquet et al. 2000). And indeed, studies employing pasireotide demonstrated that this compound is effective in reducing the secretory activity of octreotide-resistant GH-omas and of prolactinomas (Murray et al. 2004), where the inhibitory effect correlates with SSTR5 expression. (Hofland et al. 2004). These data suggest a possible clinical application for pasireotide in octreotide-resistant pituitary adenomas, in keeping with the greater affinity of this compound with SSTR5.

Besides the direct actions on pituitary cells, SRIF and its analogs also have indirect effects, since they inhibit production and secretion of many angiogenic factors, therefore reducing tumor growth rate (Barrie et al. 1993). Neoangiogenesis is fundamental for tumor growth and one of the main factors promoting this process is vascular endotelial growth factor (VEGF). Previous evidence indicated that VEGF expression may be related to pituitary tumor growth (McCabe et al. 2002). A recent study investigated the possible effects of the multireceptor SRIF ligand, pasireotide, on 
VEGF secretion and cell viability in 25 human NFA primary cultures (Zatelli et al. 2007). Expression analysis showed that all the samples expressed, besides $\alpha$-subunit, also VEGF and VEGFR-1 or 2 (or both). On the contrary, SSTR expression pattern was highly variable. According to VEGF secretion response to SRIF, two different groups were identified: the "responder" group, where VEGF secretion was reduced by at least $15 \%$ after treatment with SRIF at $10 \mathrm{nM}$, and the "non responder" group which failed to respond to SRIF. Pasireotide at $10 \mathrm{nM}$ was effective in reducing VEGF secretion in the first group, but was completely ineffective in the latter. In addition, SRIF and pasireotide completely abrogated Forskolin-induced VEGF secretion and prevented the promoting effects of VEGF on NFA cell viability in the responder group. Moreover, these primary cultures had a reduced SSTR5 expression as compared to the "non responders". These data suggest that SSTR5 is not involved in transducing the inhibitory effects of pasireotide on NFA. On the other hand, pasireotide can reduce NFA cell viability by inhibiting VEGF secretion, likely interacting with SSTR subtypes different from SSTR5. Furthermore, these data suggest that the multireceptorSSTR agonist might be useful in medical therapy of selected NFA.

In conclusion, the inhibitory effects of SRIF analogs in vitro depend on tissue SSTR expression pattern, on agonists binding profile, and on SSTR effector coupling. Further studies are therefore needed to elucidate the mechanisms underlying such effects and to verify possible clinical applications.

\section{ACKNOWLEDGEMENTS}

This work was supported by grants from the Italian Ministry of University and Scientific and Technological Research (University of Ferrara: 60\%-2006 and MIUR 2006067811_003), Fondazione Cassa di Risparmio di Ferrara, Associazione Italiana per la Ricerca sul Cancro, and the Associazione Ferrarese dell'Ipertensione Arteriosa to the University of Ferrara. 


\section{REFERENCES}

Andersen, M., Bjerre, P., Schroder, H.D., Edal, A., Hoilund-Carlsen, P.F., Pedersen, P.H., Hagen, C., 2001. In vivo secretory potential and the effect of combination therapy with octreotide and cabergoline in patients with clinically non-functioning pituitary adenomas. Clin. Endocrinol. 54, 23-30.

Batista, D.,L., Zhang, X., Gejman, R., Ansell, P.J., Zhou, Y., Johnson, S.A., Swearingen, B., Hedley-Whyte, E.T., Stratakis, C.A., Klibanski, A., 2006. The effects of SOM230 on cell proliferation and adrenocorticotropin secretion in human corticotroph pituitary adenomas. J. Clin. Endocrinol. Metab., 91, 4482-4488.

Barrie, R., Woltering, E.A., Hajarizadeh, H., Mueller, C., Ure, T., Fletcher, W.S., 1993. Inhibition of angiogenesis by somatostatin and somatostatin-like compounds is structurally dependent. J. Surg. Res. 55, 446-450.

Ben-Shlomo, A., Wawrowsky, K.A., Proekt, I., Wolkenfeld, N.M., Ren, S-G, Taylor, J., Culler, M.D., Melmed, S., 2005. Somatostatin receptor type 5 modulates somatostatin receptor type 2 regulation of adrenocorticotropin secretion. J. Biol. Chem. 280,24011-24021.

Casarini, A.P., Pinto, E.M., Jallad, R.S., Giorni, R.R., Giannella-Neto, D., Bronstein, M.D. 2006. Dissociation between tumor shrinkage and hormonal response during somatostatin analog treatment in an acromegalic patient: preferential expression of somatostatin receptor subtype 3. J. Endocrinol. Invest. 29, 826-30.

Colao, A., Di Sarno, A., Marzullo, P., Di Somma, C., Cerbone, G., Landi, M.L., Faggiano, A., Merla, B., Lombardi, G., 2000. New medical approaches in pituitary adenomas. Horm. Res. 53 (Suppl 3), 76-87.

Danila, D.C., Haidar, J.N., Zhang, X., Katznelson, L., Culler, M.D., Klibanski, A., 2001. Somatostatin receptor-specific analogs: effects on cell proliferation and growth hormone secretion in human somatotroph tumors. J. Clin. Endocrinol. Metab. 86, 2976-2981. 
Dasgupta, P., Singh, A.T., Mukherjee, R., 1999. Antiproliferative and GH-inhibitory activity of chimeric peptides consisting of GHRP-6 and somatostatin. Biochem. Biophys. Res. Commun. $259,379-384$.

Duran-Prado, M., Bucharles, C., Gonzalez, B.J., Vazquez-Martinez, R., Martinez-Fuentes, A.J., Garcia-Navarro, S., Rhodes, S.J., Vaudry, H., Malagon, M.M., Castano, J.P., 2007. Porcine somatostatin receptor 2 displays typical pharmacological sst2 features but unique dynamics of homodimerization and internalization. Endocrinology 148, 411-421.

Ferjoux, G., Bousquet, C., Cordelier, P., Benali, N., Lopez, F., Rochaix, P., Buscail, L., Susini, C., 2000. Signal transduction of somatostatin receptors negatively controlling cell proliferation. J. Physiol. 94, 205-210

Ferrante, E., Pellegrini, C., Bondioni, S., Peverelli, E., Locatelli, M., Gelmini, P., Luciani, P., Peri, A., Mantovani, G., Bosari, S., Beck-Peccoz, P., Spada, A., Lania, A., 2006. Octreotide promotes apoptosis in human somatotroph tumor cells by activating somatostatin receptor type 2 . Endoc. Relat. Cancer 13, 955-962.

Gasperi, M., Petrini, L., Pilosu, R., Nardi, M., Marcello, A., Mastio, F., Bartalena, L., Martino, E., 1993. Octreotide treatment does not affect the size of most non-functioning pituitary adenomas. J. Endocrinol. Invest. 16, 541-543.

Hofland, L.J., van der Hoek, J., van Koetsveld, P.M., de Herder, W.W., Waaijers, M., Sprij-Mooij, D., Bruns, C., Weckbecker, G., Feelders, R., van der Lely, A.J., Beckers, A., Lamberts, S.W. 2004 The novel somatostatin analog SOM230 is a potent inhibitor of hormone release by growth hormone- and prolactin-secreting pituitary adenomas in vitro. J Clin Endocrinol Metab. 89,157785.

Hofland, L.J., van der Hoek, J., Feelders, R., van Aken, M.O., van Koetsveld, P.M., Waaijers, M., Sprij-Mooij, D., Bruns, C., Weckbecker, G., de Herder, W.W., Beckers, A., Lamberts, S.W. The multi-ligand somatostatin analogue SOM230 inhibits ACTH secretion by cultured human corticotroph adenomas via somatostatin receptor type 5. Eur J Endocrinol 152,645-654. 
Hubina, E., Nanzer, A.M., Hanson, M.R., Ciccarelli, E., Losa, M., Gaia, D., Papotti, M., Terreni, M.R., Khalaf, S., Jordan, S., Czirjak, S., Hanzely, Z., Nagy, G.M., Goth, M.I., Grossman, A.B., Korbonits, M.. 2006 Somatostatin analogues stimulate p27 expression and inhibit the MAP kinase pathway in pituitary tumours. Eur. J. Endocrinol. 155, 371-379.

Jaquet, P., Ouafik, L.H., Saveanu, A., Gunz, G., Fina, F., Dufour, H., Culler, M.D., Moreau, J.P., Enjalbert, A. 1999 Quantitative and Functional Expression of Somatostatin Receptor Subtypes in Human Prolactinomas. J Clin Endocrinol Metab 84,3268-3276

Jaquet, P., Saveanu, A., Gunz, G., Fina, F., Zamora, A.J., Grino, M., Culler, M.D., Moreau, J.P., Enjalbert, A., Ouafik, L.H., 2000. Human somatostatin receptor subtypes in acromegaly: distinct patterns of messenger ribonucleic acid expression and hormone suppression identify different tumoral phenotypes. J. Clin. Endocrinol. Metab. 85, 781-792.

Luciani, P., Gelmini, S., Ferrante, E., Lania, A., Benvenuti, S., Baglioni, S., Mantovani, G., Cellai, I., Ammannati, F., Spada, A., Serio, M. Peri, A, 2005. Expression of the antiapoptotic gene seladin-1 and octreotide-induced apoptosis in growth hormone-secreting and nonfunctioning pituitary adenomas. J. Clin. Endocrinol. Metab. 90, 6156-6161.

Matrone, C., Pivonello, R., Colao, A., Cappabianca, P., Cavallo, L.M., Del Basso De Caro, M.L., Taylor, J.E., Culler, M.D., Lombardi, G., Di Renzo, G.F., Annunziato, L., 2004. Expression and function of somatostatin receptor subtype 1 in human growth hormone secreting pituitary tumors deriving from patients partially responsive or resistant to long-term treatment with somatostatin analogs. Neuroendocrinol. 79, 142-148.

McCabe, C.J., Boelaert, K., Tannahill, L.A., Heaney, A.P., Stratford, A.L., Khaira, J.S., Hussain, S., Sheppard, M.C., Franklyn, J.A., Gittoes, N.J. 2002. Vascular endothelial growth factor, its receptor KDR/Flk-1, and pituitary tumor transforming gene in pituitary tumors. J. Clin. Endocrinol. Metab. 87, 4238-4244. 
Murray, R.D., Kim, K., Ren, S.G., Lewis, I., Weckbecker, G., Bruns, C., Melmed, S. 2004 The novel somatostatin ligand (SOM230) regulates human and rat anterior pituitary hormone secretion. .J. Clin. Endocrinol. Metab. 89, 3027-32.

Oppizzi, G., Cozzi, R., Dallabonzana, D., Orlandi, P., Benini, Z., Petroncini, M., Attanasio, R., Micella, M., Banfi, G., Possa, M., 1998. Scintigraphic imaging of pituitary adenomas: an in vivo evaluation of somatostatin receptors. J. Endocrinol. Investm 21, 512-519.

Panetta, R., Patel, Y.C., 1995. Expression of mRNA for all five human somatostatin receptors (hSSTR1-5) in pituitary tumors. Life Sci. 56, 333-342.. Ren, S.G., Taylor, J.T., Dong, J., Yu, R., Culler, M.D., Melmed, S., 2003. Functional association of somatostatin receptor subtypes 2 and 5 in inhibiting human growth hormone secretion. J. Clin. Endocrinol. Metab. 88, 4239-4245.

Resmini, E., Dadati, P., Ravetti, J.L., Zona, G., Spaziante, R., Saveanu, A., Jaquet, P., Culler, M.D., Bianchi, F., Rebora, A., Minuto, F., Ferone, D. 2007 Rapid pituitary tumor shrinkage with dissociation between antiproliferative and antisecretory effects of a long-acting octreotide in an acromegalic patient. J. Clin. Endocrinol. Metab. 92:1592-9.

Richardson, U.I., Schonbrunn, A. 1981 Inhibition of adrenocorticotropin secretion by somatostatin in pituitary cells in culture. Endocrinology 108,281-290.

Rocheville, M., Lange, D.C., Kumar, U., Patel, S.C., Patel, R.C., Patel, Y.C., 2000. Receptors for dopamine and somatostatin: formation of hetero-oligomers with enhanced functional activity. Science $288,154-157$.

Saveanu, A., Gunz, G., Doufour, H., Caron, P., Fina, F., Ouafik, L., Culler, M.D., Moreau, J.P., Enjalbert, A., Jaquet, P., 2001. BIM-23244, a somatostatin receptor subtype 2- and 5- selective analog with enhanced efficacy in suppressing growth hormone $(\mathrm{GH})$ from Octreotide-resistant human GH-secreting adenomas. J. Clin. Endocrinol. Metab. 86, 140-145.

Sharma, K., Patel, Y.C., Srikant, C.B., 1996 Subtype-selective induction of wild-type p53 and apoptosis, but not cell cycle arrest, by human somatostatin receptor 3. Mol. Endocrinol. 10,:168896. 
Shimon, I., Taylor, J.E., Dong, J.Z., Bitonte, R.A., Kim, S., Morgan, B., Coy, D.H., Culler, M.D., Melmed, S., 1997. Somatostatin receptor subtype specificity in human fetal pituitary cultures. Differential role of SSTR2 and SSTR5 for growth hormone, thyroid stimulating hormone, and prolactin regulation. J. Clin. Invest. 99:789-798

Shimon, I., Yan, X., Taylor, J.E., Weiss, M.H., Culler, M.D., Melmed, S., 1997. Somatostatin receptor (SSTR) subtype-selective analogues differentially suppress in vitro growth hormone and prolactin in human pituitary adenomas. Novel potential therapy for functional pituitary tumors. J. Clin. Invest. 100, 2386-2392.

Theodoropoulou, M., Zhang, J., Laupheimer, S., Paez-Pereda, M., Erneux, C., Florio, T., Pagotto, U., Stalla, G.K., 2006. Octreotide, a somatostatin analogue, mediates its antiproliferative action in pituitary tumor cells by altering phosphatidylinositol 3-kinase signaling and inducing Zac1 expression. Cancer Res. 66,1576-1582.

Tulipano, G., Bonfanti, C., Dilani, G., Billeci, B., Bollati, A., Cozzi, R., Maira, G., Murphy, W.A., Ponesi, C., Turazzi, S., Giustina, A., 2001. Differential inhibition of growth hormone secretion by analogs selective for somatostatin receptor subtypes 2 and 5 in human growth-hormone-secreting adenoma cells in vitro. Neuroendocrinology 73,344-51.

Tulipano, G., Stumm, R.., Pfeiffer, M., Kreienkamp, H.J., Höllt, V., Schulz, S. 2004 Differential beta-arrestin trafficking and endosomal sorting of somatostatin receptor subtypes. J. Biol. Chem. 279:21374-82.

van der Hoek, J., Waaijers, M., van Koetsveld, P.M., Sprij-Mooij, D., Feelders, R.A., Schmid, R.A., Schoeffter, P., Hoyer, D., Cervia, D., Taylor, J.E., Culler, M.D., Lamberts S.W.J, Hofland, L.J. 2005. Distinct functional properties of native somatostatin receptor subtype 5 compared with subtype 2 in the regulation of ACTH release by corticotroph tumor cells. Am. J. Physiol. Endocrinol. Metab. 289: E278-E287. 
Weckbecker, G., Lewis, I., Albert, R., Schmid, H.A., Hoyer, D., Bruns, C., 2003. Opportunities in somatostatin research: biological, chemical and therapeutic aspects. Nat. Rev. Drug Discov. 2, 999-1017.

Zatelli, M.C., Tagliati, F., Taylor, J.E., Rossi, R., Culler, M.D., degli Uberti, E.C., 2001. Somatostatin receptor subtypes 2 and 5 differentially affect proliferation in vitro of the human medullary thyroid carcinoma cell line TT. J. Clin. Endocrinol. Metab. 86, 2161-2169.

Zatelli, M.C., Piccin, D., Tagliati, F., Ambrosio, M.R., Margutti, A., Padovani, R., Scanarini, M., Culler, M.D., degli Uberti, E.C., 2003. Somatostatin receptor subtype 1 selective activation in human growth hormone- and prolactin-secreting pituitary adenomas: effects on cell viability, growth hormone and prolactin secretion. J. Clin. Endocrinol. Metab. 88,2797-2802.

Zatelli, M.C., Piccin, D., Bottoni, A., Ambrosio, M.R., Margutti, A., Padovani, R., Scanarini, M., Taylor, J.E., Culler, M.D., Cavazzini, L., degli Uberti, E.C., 2004. Evidence for differential effects of selective somatostatin receptor subtype agonists on alpha-subunit and chromogranin A secretion and on cell viability in human non-functioning pituitary adenomas in vitro. J. Clin. Endocrinol. Metab. 89, 5181-5188

Zatelli, M.C., Piccin, D., Tagliati, F., Bottoni, A., Ambrosio, M.R., Margutti, A., Scanarini, M., Bondanelli, M., Culler, M.D., degli Uberti, E.C., 2005. Dopamine receptor subtype 2 and somatostatin receptor subtype 5 expression influences somatostatin analogs effects on human somatotroph pituitary adenomas in vitro. J. Mol. Endocrinol. 35, 333-341.

Zatelli, M.C., Piccin, D., Tagliati, F., Bottoni, A., Luchin, A., degli Uberti, E.C., 2005. SHP-1 restrains cell proliferation in human medullary thyroid carcinoma. Endocrinology 146:26922698.

Zatelli, M.C., Piccin, D., Vignali, C., Tagliati, F., Ambrosio, M.R., Bondanelli, M., Cimino, V., Bianchi, A., Schmid, H.A., Scanarini, M., Pontecorvi, A., De Marinis, L., Maira, G., degli Uberti, E.C., 2007. Pasireotide, a multiple somatostatin receptor subtypes ligand, reduces cell viability in 
non-functioning pituitary adenomas by inhibiting vascular endothelial growth factor secretion.

Endocr. Relat. Cancer 14, 91-102. 
List of changes made to Ms \# MCE-D-07-00116

1. Page 3, paragraph 1, line 3: the words "a SRIF analog preferentially binding with high affinity SSTR2 and less affinity SSTR5" have been added instead of the words "a SRIF analog interacting with both SSTR2 and SSTR5".

2. Page 3, paragraph 1, line 11: the following paragraphs have been added: "Similarly, an important tumor shrinkage has been described in an acromegalic patient during primary therapy with SRIF analogs, in the absence of hormonal normalization (Casarini et al. 2006). In this case, the lack of antisecretory action of octreotide, a SRIF analog preferentially binding with high affinity SSTR2 and less affinity SSTR5, was in keeping with the absence of SSTR2 and SSTR5 expression by the tumor, which expressed almost exclusively SSTR3. The latter SSTR subtype has been indeed demonstrated to transduce important antiproliferative signals, since its activation causes apoptosis in heterlogous expression systems (Sharma et al. 1996). Further support to the hypothesis that antiproliferative effects are independent of antisecretory actions of SRIF analogs is provided by a recent report, describing the case of an acromegalic patient displaying dramatic tumor shrinkage during primary therapy with octreotide, without hormonal normalization. Again, in vitro SRIF and its analogs at $10 \mathrm{nM}$ induced a scant antisecretory effect, but potently inhibited thymidine incorporation. This effect was evident for compounds interacting with SSTR5, in keeping with the finding that SSTR5 expression levels were greater than SSTR2 in the tissue (Resmini et al. 2007). These findings further underline that activation of multiple receptors by new analogs may better control tumor cell activity and that SRIF analogs may induce tumor shrinkage despite the lack of effect on GH secretion.

Further studies highlighted the importance of SSTR expression pattern in GH-secreting pituitary adenomas in respect to the inhibitory effects of SRIF analogs. In a series of 16 adenomas a selective SSTR5 agonist (BIM-23268 at 0.01-1 $\mu \mathrm{M}$ ) was more potent of a selective SSTR2 agonist (NC-4-28B at $0.01-1 \mu \mathrm{M}$ ) in reducing GH secretion in primary cultures not responding to SRIF (Tulipano et al. 2001). These results suggest that SRIF analogs with greater affinity for SSTR5 might enhance treatment potency and spectrum in acromegaly, especially in octreotideresistant patients.

3. Information concerning concentration of use of SRIF analogs as well as SSTR expressiion pattern in each experimental setting have been added throughout the manuscript.

4. Page 4, paragraph 1, line 14: the following paragraph has been added: "Tulipano et al. also demonstrated that, after ligand binding, SSTR2 is phosphorylated by G protein-coupled receptor kinase 2 , forms a stable complex with beta-arrestin and then internalizes into endocytic vesicles. 
However, SSTR2 is rapidly resensitized and recycled to the plasma membrane. Conversely, after activation, SSTR3 and SSTR5 rapidly dissociate from beta-arrestin and undergo ubiquitindependent lysosomal degradation, preventing plasma membrane recycling (Tulipano et al. 2004). These findings might explain the different down-stream effects observed in different experimental settings."

5. Page 6, paragraph 1, line 14: the paragraph "This effect might explain the lack of efficacy of medical treatment by means of octreotide or Lan, compounds mainly interacting with SSTR2 and less with SSTR5, in some NFA (Oppizzi et al. 1998, Andersen et al. 2001, Colao et al. 2000, Gasperi et al. 1993). Moreover, our findings might provide a possible explanation for the increase in tumor volume rarely observed during such therapy (Andersen et al. 2001). These results suggest that indication for medical therapy with octreotide or Lan in NFA patients with SSTR5 expressing tumors should be critically discussed until clinical evidence for beneficial effects has clearly been demonstrated." has been addaed instead of the paragraph "This effect might explain the lack of efficacy of medical NFA treatment by means of Octreotide or Lanreotide, compounds mainly interacting with SSTR2 and SSTR5 (Oppizzi et al. 1998, Andersen et al. 2001, Colao et al. 2000, Gasperi et al. 1993). Moreover, our findings could explain the increase in the tumor volume observed in some cases during such therapy (Andersen et al. 2001). These results suggest that indication for medical therapy with Octreotide or Lanreotide in NFA patients should be critically discussed until clinical evidence for beneficial effects has clearly been demonstrated".

6. Page 7, paragraph 2, line 1: the paragraph "Selective SSTR5 activation has previously been demonstrated to promote cell proliferation in a medullary thyroid carcinoma (MTC) cell line (Zatelli et al. 2001), but not in GH-secreting pituitary adenomas in primary culture (Danila et al. 2001). Therefore, it is likely that SSTR agonists differently affect hormone secretion and cell proliferation depending not only on the activated receptor subtype, but also on the specific tissue. And indeed there is evidence indicating that SSTR5 is important in transducing SRIF inhibitory effects in a mouse ACTH-secreting pituitary adenoma cell line, the AtT20 cells (Richardson et al. 1981; van der Hoek et al. 2005). Indeed, upon SRIF treatment, SSTR5 persists at the membrane level while SSTR2 rapidly internalizes and desensitizes (Ben-Shlomo et al. 2005). Further studies on human ACTH-pituitary adenomas in vitro demonstrated that pasireotide (SOM230, a novel SRIF analog interacting with all SSTRs except for SSTR4) at 10 $\mathrm{nM}$ significantly inhibits ACTH release in primary cultures predominantly expressing SSTR5. In addition, in these settings octreotide was less effective in reducing ACTH secretion, and dexamethasone $(10 \mathrm{nM})$ pre-treatment did not influence the sensitivity of the cells to the 
inhibitory effect of SOM230. These data indicate that SSTR5 is relatively resistant to negative control by glucocorticoids (Hofland et al 2005), as also suggested by an animal model. Indeed, treatment with pasireotide significanlty down-regulated SSTR2 but not SSTR5 expression. in the AtT20 cell line (van der Hoek et al. 2005). These results have been further strengthened by the recent evidence that pasireotide is capable of reducing both ACTH secretion and cell proliferation of human corticotroph pituitary adenoma cultures, where receptor expression has been characterized at protein level (Batista et al. 2006). All together, these results provide further support to the hypothesis that SSTR5 has an inhibitory activity on corticotroph cell functions and is required to warrant efficacy of SRIF analogs in the treatment of patients with ACTH-secreting pituitary adenomas." has been added instead of the paragraph "Selective SSTR5 activation has previously been demonstrated to promote cell proliferation in a medullary thyroid carcinoma (MTC) cell line (Zatelli et al. 2001), but not in GH-secreting pituitary adenomas in primary culture (Danila et al. 2001). Therefore, it is likely that SSTR agonists differently affect hormone secretion and cell proliferation depending not only on the specific activated receptor subtype, but also on the specific tissue".

7. Page 8, paragraph 2, line 1: the paragraph "It has been recently demonstrated that treatment of dispersed GH-secreting pituitary adenoma cells, having a variable SSTR expression pattern, with octreotide at $10 \mathrm{nM}$, as well as with pasireotide at $10 \mu \mathrm{M}$, up-regulates the expression of a cyclin-dependent kinase inhibitor, p27, possibly resulting in cell cycle inhibition (Hubina et al. 2006). Besides the antiproliferative effects, previous studies showed that pasireotide at $10 \mathrm{nM}$ is capable of significantly inhibiting GH secretion in primary cultures deriving from human GHsecreting pituitary adenomas, mainly expressing SSTR2 and SSTR5 (Hofland et al. 2004; Murray et al. 2004). SSTR2 expression was found to be crucial, as underlined by the positive correlation between SSTR2 mRNA levels and pasireotide effects in vitro. Such correlation was not found for SSTR5, suggesting that pasireotide exerts its inhibitory effects on GH-secreting pituitary adenomas mainly interacting with SSTR2 (Hofland et al. 2004). This finding is in keeping with a previous report showing that SSTR2 but not SSTR5 mRNA expression correlates with the extent of GH inhibition induced by SRIF in GH-secreting pituitary adenomas (Jaquet et al. 2000). On the other hand, there is evidence indicating that in prolactinomas and in mixed GH/PRL pituitary adenomas, PRL secretion inhibition is mainly transduced by SSTR5 (Jaquet et al. 1999; Jaquet et al. 2000). And indeed, studies employing pasireotide demonstrated that this compound is effective in reducing the secretory activity of octreotide-resistant GHomas and of prolactinomas (Murray et al. 2004), where the inhibitory effect correlates with SSTR5 expression. (Hofland et al. 2004). These data suggest a possible clinical application for 
pasireotide in octreotide-resistant pituitary adenomas, in keeping with the greater affinity of this compound with SSTR5" has been added instead of the paragraph "It has been recently demonstrated that treatment of dispersed GH-secreting pituitary adenoma cells with octreotide, as well as pasireotide (SOM230, a novel SRIF analog interacting with all SSTRs except for SSTR4), up-regulates the expression of a cyclin-dependent kinase inhibitor, p27, possibly resulting in cell cycle inhibition (Hubina et al. 2006)."

8. Page 8, paragraph 2, line 1: the sentences “. In addition, SRIF and pasireotide completely abrogated Forskolin-induced VEGF secretion and prevented the promoting effects of VEGF on NFA cell viability in the responder group. Moreover, these primary cultures had a reduced SSTR5 expression as compared to the "non responders". These data suggest that SSTR5 is not involved in transducing the inhibitory effects of pasireotide on NFA. On the other hand, pasireotide can reduce NFA cell viability by inhibiting VEGF secretion, likely interacting with SSTR subtypes different from SSTR5. Furthermore, these data suggest that the multireceptorSSTR agonist might be useful in medical therapy of selected NFA." have been added instead of "In addition, SRIF and pasireotide completely abrogated Forskolin-induced VEGF secretion and prevented the promoting effects of VEGF on NFA cell viability. These data indicate that pasireotide can reduce NFA cell viability by inhibiting VEGF secretion, and suggest that the multireceptor-SSTR agonist pasireotide might be useful in medical therapy of selected NFA."

9. The following references have been added:

Batista, D.,L., Zhang, X., Gejman, R., Ansell, P.J., Zhou, Y., Johnson, S.A., Swearingen, B., Hedley-Whyte, E.T., Stratakis, C.A., Klibanski, A., 2006. The effects of SOM230 on cell proliferation and adrenocorticotropin secretion in human corticotroph pituitary adenomas. J. Clin. Endocrinol. Metab., 91, 4482-4488.

Casarini, A.P., Pinto, E.M., Jallad, R.S., Giorni, R.R., Giannella-Neto, D., Bronstein, M.D. 2006. Dissociation between tumor shrinkage and hormonal response during somatostatin analog treatment in an acromegalic patient: preferential expression of somatostatin receptor subtype 3. J. Endocrinol. Invest. 29, 826-30.

Hofland, L.J., van der Hoek, J., van Koetsveld, P.M., de Herder, W.W., Waaijers, M., Sprij-Mooij, D., Bruns, C., Weckbecker, G., Feelders, R., van der Lely, A.J., Beckers, A., Lamberts, S.W. 2004 The novel somatostatin analog SOM230 is a potent inhibitor of hormone release by growth hormone- and prolactin-secreting pituitary adenomas in vitro. J Clin Endocrinol Metab. 89,157785.

Hofland, L.J., van der Hoek, J., Feelders, R., van Aken, M.O., van Koetsveld, P.M., Waaijers, M., Sprij-Mooij, D., Bruns, C., Weckbecker, G., de Herder, W.W., Beckers, A., Lamberts, S.W. The 
multi-ligand somatostatin analogue SOM230 inhibits ACTH secretion by cultured human corticotroph adenomas via somatostatin receptor type 5. Eur J Endocrinol 152,645-654.

Jaquet, P., Ouafik, L.H., Saveanu, A., Gunz, G., Fina, F., Dufour, H., Culler, M.D., Moreau, J.P., Enjalbert, A. 1999 Quantitative and Functional Expression of Somatostatin Receptor Subtypes in Human Prolactinomas. J Clin Endocrinol Metab 84,3268-3276

Murray, R.D., Kim, K., Ren, S.G., Lewis, I., Weckbecker, G., Bruns, C., Melmed, S. 2004 The novel somatostatin ligand (SOM230) regulates human and rat anterior pituitary hormone secretion. .J. Clin. Endocrinol. Metab. 89, 3027-32.

Resmini, E., Dadati, P., Ravetti, J.L., Zona, G., Spaziante, R., Saveanu, A., Jaquet, P., Culler, M.D., Bianchi, F., Rebora, A., Minuto, F., Ferone, D. 2007 Rapid pituitary tumor shrinkage with dissociation between antiproliferative and antisecretory effects of a long-acting octreotide in an acromegalic patient. J. Clin. Endocrinol. Metab. 92:1592-9.

Richardson, U.I., Schonbrunn, A. 1981 Inhibition of adrenocorticotropin secretion by somatostatin in pituitary cells in culture. Endocrinology 108,281-290.

Sharma, K., Patel, Y.C., Srikant, C.B., 1996 Subtype-selective induction of wild-type p53 and apoptosis, but not cell cycle arrest, by human somatostatin receptor 3. Mol. Endocrinol. 10,:168896.

Tulipano, G., Bonfanti, C., Dilani, G., Billeci, B., Bollati, A., Cozzi, R., Maira, G., Murphy, W.A., Ponesi, C., Turazzi, S., Giustina, A., 2001. Differential inhibition of growth hormone secretion by analogs selective for somatostatin receptor subtypes 2 and 5 in human growth-hormone-secreting adenoma cells in vitro. Neuroendocrinology 73,344-51.

Tulipano, G., Stumm, R.., Pfeiffer, M., Kreienkamp, H.J., Höllt, V., Schulz, S. 2004 Differential beta-arrestin trafficking and endosomal sorting of somatostatin receptor subtypes. J. Biol. Chem. 279:21374-82.

van der Hoek, J., Waaijers, M., van Koetsveld, P.M., Sprij-Mooij, D., Feelders, R.A., Schmid, R.A., Schoeffter, P., Hoyer, D., Cervia, D., Taylor, J.E., Culler, M.D., Lamberts S.W.J, Hofland, L.J. 2005. Distinct functional properties of native somatostatin receptor subtype 5 compared with subtype 2 in the regulation of ACTH release by corticotroph tumor cells. Am. J. Physiol. Endocrinol. Metab. 289: E278-E287. 